\title{
Temporal Variations of Water Quality Parameters, Phytoplankton, And Invertebrates In Environmental Change Hotspots: A Case of Lake Wamala, Uganda
}

\author{
DOI: https://doi.org/10.24297/jaa.v10i0.8396
}

*Naigaga Shamim, Ogutu-Ohwayo Richard, Okello William, Natugonza Vianny, Musinguzi Laban, Olokotum Mark, Gandhi Willy, Magezi Godfrey, Kiggundu Vincent

*College of Agriculture, Auburn University, 103 comer hall, Alabama, USA

National Fisheries Resources Research Institute (NaFIRRI), P.O. Box 343, Jinja, Uganda

*shamimnaigaga18@gmail.com, ogutuohwayo@yahoo.com,wiokello@yahoo.com, viannynatugonza@yahoo.com, musinguzilaban@ymail.com,markolokotum@yahoo.com, gpabire@yahoo.comgmagezi@yahoo.com, vkiggundu@hotmail.com

\begin{abstract}
Lake Wamala (Uganda) is a small shallow lake (maximum mean depth $=4.5 \mathrm{~m}$ ) that has periodically undergone fluctuations in depth and area because of changes in rainfall, temperature and wind speed. No study, however, has been done to assess how these changes, in addition to catchment degradation, which are likely to intensify in future, have affected aquatic productivity processes. Data on Secchi depth (SD), turbidity, conductivity, dissolved oxygen (DO), total phosphorous (TP), soluble reactive phosphorus (SRP), soluble reactive silicon $(\mathrm{SRSi})$, ammonia $\left(\mathrm{NH}_{4}-\mathrm{N}\right)$, nitrite nitrogen $\left(\mathrm{NO}_{2}-\mathrm{N}\right)$, nitrate nitrogen $\left(\mathrm{NO}_{3}-\mathrm{N}\right)$, Chlorophyl a, composition and abundance of algae, and invertebrates were compared between periods 1998-2000 and 2011-2013. Results showed a twofold increase in conductivity and TP, a threefold increase in SRSi, chlorophyll a $>25 \mu \mathrm{g} \mathrm{I}^{-1}$, and persistence by low water transparency (SD $<0.7 \mathrm{~m}$ ). In consequence, algal biomass increased by $>70 \%$, with emergence of new species, especially among the dinoflagellate and euglenophyte groups. Although rotifers, which are known to have capacity to withstand stressful habitat conditions, dominated the zooplankton, their density decreased by $>80 \%$. The phantom-midge, chaoborus, and the midge, chironomid, larvae dominated macro-invertebrate, but did not show clear trends between the two periods.
\end{abstract}

Keywords: Climate change, cyanobacteria, eutrophication, Lake Wamala, plankton productivity

\section{Introduction}

Physical and chemical environment of water, including water transparency, conductivity, dissolved oxygen and nutrients, plankton productivity, and feeding interactions determine composition and yield of fishes [1, 2]. Seasonal and interannual variations in these conditions are known to reflect changes in the watershed as well as climate [3, 4], but limited work has been done with respect to small and shallow wetland-dominated tropical lakes. Consequently, for such lakes, studies that attempt to attribute changes in fish stocks to watershed disturbance and climate variability are subject to conjectures because of missing information on influence of the these factors on primary aquatic productivity.

Climate variability and change, through its influence on both water availability and quality, can alter the composition of plankton communities $[5,6]$, and the changes can be transmitted to higher trophic levels $[7,8$, 9]. Cell size and the proportions of different elements that constitute the phytoplankton are some of the ecophysiological traits affected by variability in climate variables $[10,11]$. The effect on these traits can cascade to higher trophic levels and influence diversity, size, composition and distribution of zooplankton, macroinvertebrates and fish communities. These changes are exacerbated by land use and land cover change within the catchment area [3]. 
Aquatic productivity processes have been linked to changes in climate, because the later controls the intensity of wind, temperature and rainfall that determine nutrient loading, mixing dynamics, primary productivity and fish yield $[12,13,14]$. The magnitude and direction of the responses by aquatic ecosystems depend on morphometric characteristics of individual systems, such as surface area and depth. Small and shallow lakes have a high area to volume ratio and are therefore more influenced by wind intensity, which may induce polymixis, and increase sediment-water interactions that alter turbidity, nutrient cycling, and dissolved oxygen concentrations [14]. Climatic variability and change are expected to affect these processes, and there is a need to understand them in order to predict future of fisheries and livelihoods of fishing communities.

According to the Intergovernmental Panel on Climate Change (IPCC), climate variability and change that have been intensifying since 1970s have been accompanied by increase in temperature, alteration in wind speed and rainfall patterns in different parts of the world [15]. Temperature and rainfall in some parts within the East African region have increased [16] and, in Uganda, for instance, greater than average rainfall and temperature increase of $>0.04{ }^{\circ} \mathrm{C}$ year ${ }^{-1}$ have been recorded around some aquatic systems during the last decade [16]. Increase in temperature can lead to high evaporation rates and, together with changes in rainfall and activities within in the watershed, alter runoff, increase siltation, affect water balance, and lake water levels [17]. Expected consequences of such changes include disruption of water column stability, loading of nutrients into aquatic systems, which, in turn, affect fisheries and livelihoods of fisheries dependent communities.

These changes are well documented in large tropical lakes, but not in shallow wetland dominated lakes. In Lake Victoria, for instance, climate warming triggered excessive nutrient loading, especially phosphorus, during 1980s [3]. This was accompanied by a shift in phytoplankton abundance from diatoms to blue green algae (cyanobacteria), since the later could fix atmospheric nitrogen and were therefore not $\mathrm{N}$-limited [18, 19]. The composition of diatoms shifted from the large Aulocoseira sp. to small thinly silicified forms, such as Nitzschia sp., which can grow at lower concentrations of silicon [3]. Eutrophication, triggered by climate warming, also, enhanced anoxia and skewed the composition of benthic invertebrates to the dominance of the lake fly larvae, Chironomus sp., Chaoborus sp., although at much reduced densities. Before the intensification of climate warming in $1970 \mathrm{~s}$, the lake fly larvae were estimated at $3000-4000$ ind. $\mathrm{m}^{-2}$ (75\% of them were Chaoborus spp.) [20] but, the most recent data give densities at 89-286 $\mathrm{m}^{-2}$ in Hannington Bay, 136-2262 ind. $\mathrm{m}^{-2}$ in Fielding Bay and 72-1629 ind. $\mathrm{m}^{-2}$ in Murchison Bay [21]. Although the densities of these organisms have decreased, the Chaoborus sp. are still one of the dominant benthic invertebrates because they can tolerate low oxygen conditions that characterise the hypolimnion under stratified conditions [22]. It is not known whether such changes are also apparent in small and shallow wetland dominated lakes, some of which have been designated environmental change hotspots.

\section{Lake Wamala as an environmental change hot spot}

Lake Wamala (Fig. 1) has been designated as one of the environmental change hot spots in Africa by the United Nations Environment Programme [23]. The highest recorded surface area of the lake is $250 \mathrm{~km}^{2}$, and the maximum mean depth is $4.5 \mathrm{~m}$ [24]. Lake Wamala almost dried up during the period 1984-1995, when its surface area was reduced by $>50 \%$, and its mean depth by $>70 \%$ as a result of persistent drought [23]. The lake regained its surface area and depth in 1999, following El Nino rains in 1997 [23], but has been shrinking since 2000 , despite rainfall, which accounts $\sim 80 \%$ of the water input, being above average [16]. Because there is no water abstraction from the lake for large scale purposes, such as irrigation and hydro electricity generation, this decrease can be attributed to high evaporation rates caused by increased ambient temperature $\left(>0.04{ }^{\circ} \mathrm{C}_{\text {year }}{ }^{-1}\right)$ and wind speed [16]. This implies that there may be an increase in rainfall, but the water gain may be offset by increased evaporation associated with increased temperature and wind speed. The implications of such changes, in addition to activities in the catchment, for the primary productivity processes need to be understood in order to predict the future of fisheries.

A recent study, for example, on the diet of Nile tilapia, Oreochromis niloticus (Linnaeus, 1758), in Lake Wamala [16] showed that the fish had diversified its well-known algal diet, and included insects, fish, and detritus, 
especially during the dry seasons. The authors suggested that the inclusion of other food types, especially of animal origin, was an adaptation response to widen the food resource base, basing on the notion that the preferred phytoplankton sources could have declined because of increasing temperatures, like it was in Lake Kariba [13]. This conclusion, however, seemed to be a conjecture because it was made without examination of the changes in either phytoplankton composition or biomass in Lake Wamala. It is urgent, therefore, to study the changes in primary productivity processes so as to adequately link biological aspects of fishes to climate variability and change.

The aim of this study was to investigate seasonal and interannual changes in aspects of primary productivity, and determine as to whether climate variability, whose effect on water levels of Lake Wamala has been discussed [16], as well as activities in the catchment [25] played a role. The observations were placed in the context of baseline data because we compared data for periods 1998-2000 and 2011-2013 that may be too short to conclude about the effect of climate variability and change. Nonetheless, we believe that this information will be important to understanding what may happen to productivity of small and shallow lake ecosystems, in future, as climate variability and change, and activities in the catchment area intensify.

The productivity aspects were examined to include: Secchi depth (SD), turbidity, conductivity and dissolved oxygen (DO); nutrients, including total phosphorous (TP), soluble reactive phosphorus (SRP), soluble reactive silicon (SRSi), ammonium $\left(\mathrm{NH}_{4}-\mathrm{N}\right)$ nitrite nitrogen $\left(\mathrm{NO}_{2}-\mathrm{N}\right)$ and nitrate nitrogen $\left(\mathrm{NO}_{3}-\mathrm{N}\right)$; Chlorophyl $a$, composition and abundance of algae, zooplankton and macro-invertebrates. We anticipated that the increase in temperature, rainfall and wind speed observed around Lake Wamala, coupled with clearance of vegetation within the watershed, would increase nutrient loading, enhance turbidity and limit water transparency, and lower DO concentration. This would, in consequence, alter primary production and shift the composition of algae and invertebrates to those that have the capacity to persist, adjust or exploit the changed conditions.

\section{Methods}

\section{Study area}

The study was carried out on Lake Wamala in the Lake Victoria basin (Fig. 1). The climate around Lake Wamala is characterized by two wet and two dry seasons i.e., short dry (December-February), long wet (March-May), long dry (June-August) and short wet (September-November) based on the classification in Komutunga and Musiitwa [26]. A detailed description of the physical and hydrological characteristics of Lake Wamala is given in [16] and [25]. Between August 1998 and May 2000, and December 2011 and July 2013, inshore stations (within $200 \mathrm{~m}$ from the shoreline), river inlets and outlet, and open water (Fig. 1) were sampled once every three months to cover the four main seasons defined above, except for turbidity, which was only determined for July 2012 and July 2013.

\section{Sampling and analyses}

\section{Water transparency, conductivity, turbidity, and temperature}

In-situ measurements were made for water transparency $(\mathrm{m})$, conductivity $\left(\mu \mathrm{Scm}^{-1}\right)$, turbidity (NTU), and temperature $\left({ }^{\circ} \mathrm{C}\right)$. Water transparency was measured with a Secchi disk $(\varnothing=20 \mathrm{~cm})$ painted black and white by taking the average of the depth at the disappearance and that at reappearance of the disk in the water. Conductivity, turbidity, and temperature were determined using a multi-probe Hach HQ40d.

\section{DO concentration and primary production}

Water within a vertical profile, doubling the light transparency measurement, was taken using a two-litre Van Dorn sampler, beginning at the surface and working downwards. The sample was replicated by filling rapidly under shade in BOD bottles of known volume, and then held in a light proof box until samples from all depth were collected. One of the bottle was fixed immediately for the initial DO concentration, while the other two, 
one dark and the other light, were suspended using metered suspension line attached securely to an anchored buoy for one hour. Winkler method of titration was used to determine the oxygen concentration ( $\mathrm{mg} \mathrm{L}^{-1}$ ) and gross primary production $\left(\mathrm{mg} \mathrm{O}_{2} \mathrm{~m}^{-2} \mathrm{~h}^{-1}\right)$ [29].

\section{Nutrients and Chlorophyll $a$}

Water samples taken at $0.5 \mathrm{~m}$ using the two-litre Van Dorn sampler were filtered using $47 \mathrm{~mm}$ diameter GF/C filters (Whatman, Kent, Great Britain). The filters were stored frozen to be used in the analysis of chlorophyll $a$. Chlorophyll $a$ was determined using cold extraction method [27] by soaking the filters overnight at $4^{\circ} \mathrm{C}$, squeezing the filters off and absorbance measurement taken at $665 \mathrm{~nm}$ and $750 \mathrm{~nm}$. Filtrates were again filtered through $47 \mathrm{~mm}$ diameter membrane filters $(0.45 \mu \mathrm{m}$, Millipore Corporation, Bellerica, United States) for the analyses of dissolved nutrients i.e. SRP, $\mathrm{NO}_{3}-\mathrm{N}$ and $\mathrm{NH}_{4}-\mathrm{N}$. These were determined using the ammonium molybdate method [27], the sodium-salycilate method [28] and the indophenol blue method [29], respectively. Determination of $\mathrm{NO}_{2}-\mathrm{N}$, however, was made after passing the sample through the cadmium reduction column [27]. TP was determined as SRP subsequent to persulfate digestion from aliquots of the unfiltered samples [28].

\section{Phytoplankton}

Using the same water sample as for chlorophyll $a$, phytoplankton were identified and counted with the aid of an inverted microscope from Lugol fixed samples as described in Utermöhl [30]. For each sample, 400 specimen of the dominant phytoplankton genera were counted at 400 -fold magnification. Most of the genera were counted as single cells (cyanobacteria: Aphanocapsa, Anabaena, Chroococcus, Merismopedia, Microcystis; diatoms: Nitzschia; and unidentified centric diatoms, green algae, desmids, cryptomonads). Filamentous cyanobacteria were counted as single filaments (Aphanizomenon, Cylindrospermopsis, and Planktolyngbya). Planktolyngbya could be differentiated by single filaments of lowest diameter (mean \pm 1 SE $2.4 \pm 0.03 \mu \mathrm{m}$ ), composed of tightly attached cells and embedded in a colourless sheath. From each genus identified [31], cells/filaments dimensions from ten specimens were measured to calculate the biovolume according to standard geometric shapes $[32,27]$.

\section{Zooplankton}

Zooplankton were sampled using a Nansen net (60- $\mu \mathrm{m}$ mesh size and $0.25-\mathrm{m}$ diameter mouth opening). Sampling was done by vertical hauling of the net gradually from $0.5-1.0 \mathrm{~m}$ above the bottom sediments to the water surface. Three hauls were taken to make a composite sample. Each sample was preserved with a sugarformalin, in a ratio of one part formalin to 10 parts sample volume.

In the laboratory, each sample was washed with tap water over a $53 \mu \mathrm{m}$ sieve to remove the preservative and then diluted to a suitable volume, depending on the concentration of organisms in each sample. Sub-samples of 2, 2, 5 and $10 \mathrm{~mL}$ were taken with a wide bore automatic pipette from a well agitated sample. The subsample series were performed to consider the more abundant organisms in $2,2 \mathrm{~mL}$ series, and the rarer organisms in 2, 2, 5, $10 \mathrm{~mL}$ series. Each sub-sample was put into a counting chamber and examined under inverted microscope (Hund, Wetzlar, Germany) at 100 magnification for taxonomic identification, and 40 for counting. Species identification was done using published keys [33, 34], and volume densities of organisms calculated from the counts data, with reference to the sample net mouth diameter and water column depth [35].

\section{Benthic macro invertebrates}

Sediment samples were taken with a Ponar grab (Jaw area $=238.0 \mathrm{~cm}^{2}$, inner depth $=8.0 \mathrm{~cm}$ ), harnessed with a nylon rope marked at one metre intervals. Three grab hauls were taken from each sampling point and each kept separately for subsequent laboratory analysis. Each grab sample was concentrated, placed in clean, labelled sample bottle, and preserved with $5 \%$ formalin. In the laboratory, each sample was rinsed with tap 
water and spread on to a clean white plastic tray. Benthic organisms were sorted from the sediment using forceps, and the sorted sample was examined under a dissecting binocular microscope at $x 400$ magnification. Taxonomic identification was done using the guide in De Moor et al. [36]. All taxa were recorded, and individuals of each taxon enumerated to generate data for community composition and abundance

\section{Results}

\section{Physical chemical parameters}

The SD ranged between 0.5 and $0.69 \mathrm{~m}$, and only increased by about $0.1 \mathrm{~m}$ between 1999-2000 and 20112013 (Table 1). During the period 2011-2013, SD was highest $(0.66 \pm 0.03 \mathrm{~m})$ during the long wet season and lowest $(0.54 \pm 0.05 \mathrm{~m})$ during the long dry season. Mean conductivity increased from (mean) from 163-174 $\mu \mathrm{S}$ $\mathrm{cm}^{-1}$ during 1999-2000 to 321-387 $\mu \mathrm{S} \mathrm{cm}^{-1}$ during 2011-2013 (Table 1), but no seasonal trends were discerned. The DO concentrations, at the subsurface and the bottom were, respectively, $9.5-11.5 \mathrm{mg} \mathrm{L}^{-1}$ and $7.5-10 \mathrm{mg} \mathrm{L}^{-1}$ during the dry seasons and $7.8-9.0 \mathrm{mg} \mathrm{l}^{-1}$ and $5.5-9.0 \mathrm{mg} \mathrm{l}^{-1}$ during the wet seasons. Turbidity was $20.3 \pm 2.13$ NTU and 14.3 \pm 2.84 NTU during July 2012 and July 2013, respectively. These values five times higher those recorded for Napoleon gulf, Lake Victoria, during September 2011 (NaFIRRI unpublished data).

The TP concentration ranged from 200-700 $\mathrm{gg} \mathrm{L}^{-1}$ during the dry seasons and 150-200 $\mathrm{gg} \mathrm{L}^{-1}$ during wet seasons, although SRP was higher during the wet season (Fig. $2 \mathrm{a}-\mathrm{b}$ ). The concentrations of both $\mathrm{NO}_{2}-\mathrm{N}$ and $\mathrm{NO}_{3}-\mathrm{N}$ were higher during the long dry season than wet season, while $\mathrm{NH}_{4}-\mathrm{N}$ decreased during the long wet season (Fig. 2 c-e). Both primary production (Fig. 2f) and chlorophyll $a$ (Fig. 3) were higher during the wet seasons than the dry seasons. Between 1999 and 2013, TP and $\mathrm{NO}_{3}-\mathrm{N}$ doubled, SRSi increased three-fold, while Chlorophyl $a$ decreased by about 50\% (Table 1). Although Chlorophyl $a$ decreased, its values in 2012 were twice as high as those in Lake Victoria between 2005 and 2008 [4], and greater than the minimum of 25 $\mu \mathrm{gL}^{-1}$ set by Organization for Economic Co-Operation and Development (OECD) for non-degraded waters [37].

\section{Phytoplankton composition and abundance}

Between 1999 and 2013, a total of 40 genera were recorded (Table 2). Out of these, only 21 genera were recorded during 1999-2000 period, while 35 genera were recorded during 2011-2013 period. Four of the new genera that emerged belonged to cyanobacteria, three were diatoms, two dinoflagellates, two euglenophytes, and seven green algae. Overall, algal biovolume increased by $>70 \%$ between 1999-2000 and 2000-2013 period. Whereas cyanobacteria were relatively the most dominant algal taxa during the 1999-2000 period, diatoms became the most dominant taxa during 2011-2013 period (Table 3), although the former dominated during the dry seasons (Fig. 4).

\section{Invertebrate composition and abundance}

Rotifers were the most species diverse group in Lake Wamala (Table 4). The density of rotifers, on average decreased by $>80 \%$ between two periods, where other species, such as Brachionus patulus, B. quadridentatus, Euclanis sp., and Trichotria tetractis disappeared completely. Nonetheless, in terms of total volume density, for the three zooplankton groups, rotifera remained the most abundant zooplankton group. No clear trends were discerned for copepods and cladocerans, except the emergence of new species, Thermocyclops decipiens and Diaphanosoma excisum for the two groups, respectively (Table 4). The midge, Chironomid, and the phantommidge, Chaoborus, were the most abundant benthic macro-invertebrates and, in addition to Oligochaetes, which occurred at rather low densities, were the only benthic macro-invertebrates encountered in every sampling year (Table 5). Between two periods, there was emergence, among dipterans, of Clinotanypus sp., Procladius sp., Tanypus sp., and disappearance of Hydracharina and Hirudinea groups.

\section{Discussion}




\section{Physical and chemical parameters}

Between 1998 and 2013, Lake Wamala shifted in status from a seemingly mesotrophic state to hypertrophic state. Evidence of eutrophication is manifested by a >twofold increase in conductivity, $T P$, and $\mathrm{NO}_{3}-\mathrm{N}$, $>$ threefold increase in SRSi, Chlorophyll $a>25 \mathrm{\mu g} \mathrm{l}^{-1}$, persistence by low water transparency (SD $\left.<0.7 \mathrm{~m}\right)$ and in consequence, a $>70 \%$ increase in algal abundance. The area around Lake Wamala has received rainfall greater than the average of $1180 \mathrm{~mm}$ for most of the years since 2000 (16; Table 1). Increased rainfall, coupled with cultivation of the near shore wetland and use of organic fertilizers by riparian communities to diversify out the single declining fishery livelihood [25], could have accelerated allochthonous fluvial nutrient input from the surrounding agricultural catchment. The increase in concentration of some nutrients, especially phosphorus can also be attributed to the declining lake water level (Table 1) that exposes the sediment bound phosphorus where, in addition to low DO concentration during certain seasons of year, phosphorus is released into soluble forms [38]. This was manifested, in this study, by higher SRP during the dry seasons, when water level recedes, compared to the wet seasons when the lake refills (Fig. $2 b$ ).

Besides stimulating primary production, nutrient loading in Lake Wamala was also expected to increase BOD, and reduce DO concentration [39, 3, 4]. This was not noticeable, although DO concentration decreased during the short wet season (September-November). The concentration of DO, both at the surface and bottom was highest during June-August period (long dry season). This is consistent with the high DO concentration months (June-July) for Lake Victoria, attributable to deep water mixing [40,41, 19]. However, this reasoning contradicts expected situation in Lake Wamala, because most rigorous mixing is expected during the wet stormy seasons (March-May), and not during the dry seasons (June-August). But, since Lake Wamala is a small shallow lake, with maximum mean depth of $4.5 \mathrm{~m}$, frequent mixing over its entire depth is possible, given that wind speed around the lake has also increased since 2000 [26].

These events can also explain the unexpected decrease in chlorophyll $a$, countering nutrient enrichment (Table 1), suggesting that photosynthesis in Lake Wamala is light-limited. Light limitation that enhances self-shading of algae, hence lowering primary production, can be attributed to high turbidity, which, by 2012, was five times higher than that recorded in Napoleon gulf, Lake Victoria, (NaFIRRI unpublished data). High turbidity in Lake Wamala is a result of input of silt from the heavily cultivated catchment, exacerbated by increased rainfall and wind speed (16, Table 1). This gives an implication that wind speed (with an effect on mixing and turbidity) and rainfall (that enhances runoff carrying silt), which are expected to intensify in the region [15], may depress primary production, despite increase in nutrient concentration.

\section{Phytoplankton composition and abundance}

The changes in physical and chemical conditions in Lake Wamala have also been accompanied by changes algal communities. Cyanobacteria are known to be favoured than any other taxa under low DO concentration and nutrient enriched habitats [42]. In Lake Wamala, as both TP and $\mathrm{NO}_{3}-\mathrm{N}$, cyanobacteria increased by $>70 \%$. The increase, however, is inconsistent with that in Lake Victoria where, increases in TP, stimulated by a period of climate warming and increased rainfall, resulted into a complete shift from diatoms to cyanobacteria [18, 3]. In Lake Wamala, although cyanobacteria increased, the increase was exceeded by diatoms and Euglenophytes (Table 3). In Lake Victoria, also, the composition of the suppressed diatoms shifted from the large Aulocoseira sp. to small thinly silicified forms, such as Nitzschia sp., which can grow at lower concentrations of silicon [3]. The opposite happened in Lake Wamala. The genus Aulocoseira was never observed in Lake Wamala during 1999-2000 period, but emerged during 2011-2013 period (Table 2), following a threefold increase in SRSi (Table 1). The low abundance of cyanobacteria in Lake Wamala is a result of their intolerance to poor light conditions as a result of daily mixing, up to the sediments, and high turbidity. The dominance of diatoms and, more importantly the emergence Aulocoseira species, is reflective of high silicon concentration from the silt carried into the lake from the agricultural catchment, due to increased rainfall. This is also latter is consistent with findings of Sitoki et al. [43] for Rusinga channel in the Kenyan portion of Lake Victoria. 
Nonetheless, the increase in abundance of cyanobacteria observed in Lake Wamala, which can produce phytotoxins in response to increased temperature [44,45], is a possible health concern for the people who use water and other resources from the lake. Appropriate measures should be taken to advise consumers of water and fish as algal communities shift to types that produce toxins following nutrient enrichment and climate warming.

\section{Zooplankton communities and benthic macro-inverterbrates}

The small sized rotifers are believed to have capacity to withstand stressful habitat conditions [46]. However, in Lake Wamala, rotifers decreased by about $80 \%$ between 1998 and 2013. This decrease can be attributed to the shrinking of the lake, with an exacerbation of eutrophication, which are all known to lengthen the spawning time of most zooplankton, and affect their reproductive success [47, 48]. Although rotifers decreased, they remained, in terms of total biovolume, the dominant zooplankton group, suggesting that they have capacity to withstand habitat changes compared to other zooplankton groups [46].

In Lake Victoria, eutrophication, triggered by climate warming [3], changed the composition of benthic invertebrates to the dominance of the lake fly larvae, Chironomus sp. and Chaoborus sp., but at reduced densities. These midges decreased from 3000-4000 individuals $\mathrm{m}^{-2}$ [20] to $72-1629$ individuals $\mathrm{m}^{-2}$ in the northern bays of the lake towards the end of 1990s [21]. These values are close to the densities of Chironomus sp., and Chaoborus sp in Lake Wamala (Table 5), which are the most dominant benthic macro-invertebrates in the lake. These midges have high affinity for oxygen and survive under oxygen deficient conditions [49].

The changes in dominant plankton and benthic species were reflected in the food eaten by the dominant fishes. For instance, cyanobacteria and diatoms were the dominant food for Nile tilapia during wet seasons, and chironomid and chaoborus during the dry season [16]. However, the earlier assertion by Natugonza et al. [16] that Nile tilapia diversified its diet to widen the food resource base, because of possible decline of preferred phytoplankton sources with increasing temperatures, needs further investigation as the algal abundance in the lake has increased.

This study suggests that increasing human activities in the catchment, coupled with variability in climate parameters, will impact on water quality, primary and secondary production, with possible implication for fishery production and livelihoods of fisheries dependent communities. More studies, however, are needed to provide a detailed understanding of what may happen to the lake ecosystems, especially small and shallow lakes, which are important sources of water and fish for poor riparian communities, as climate variability and change and activities in the catchment area intensify.

\section{Data Availability}

Data will be available on the Harvard dataverse and it could be assessed using the title of the manuscript.

\section{Conflicts of Interest}

No conflicts exist. Submitting authors are responsible for co-authors declaring their interests.

\section{Funding Statement}

This research was funded by the Rockefeller Foundation.

\section{Acknowledgements}


Data used in this paper were collected with support from the Rockefeller Foundation during implementation of project 2011CPR209 aimed at equipping small scale fishers and riparian communities to cope with impacts of climate variability and change. We thank the National Fisheries Resources Research Institute boat crew for their valuable support.

\section{References}

1. Munday P. L., Jones G. P., Pratchett M. S. \& Williams A. J. (2008) Climate change and the future for coral reef fishes. Fish Fish. 9, 261-285

2. Pratchett M. S. \& Berumen M. L. (2008) Interspecific variation in distributions and diets of coral reef butterflyfishes (Teleostei: Chaetodontidae). J. Fish Biol. 73, 1730-1747.

3. Hecky R. E., Mugidde R., Ramlal P. S., Talbot M. R. \& Kling G. W. (2010) Multiple stressors cause rapid ecosystem change in Lake Victoria. Freshwater Biol. 55, 19-42.

4. Sitoki L., Gichuki J., Ezekiel C., Wanda F., Mkumbo O. C. \& Marshall B. (2010) The Environment of Lake Victoria (East Africa): Current Status and Historical Changes. Int. Rev. Hydrobiol. 95, 209-223.

5. Behrenfeld J. M., O'Malley T. R., Siegel A. D., McClain R. C., Sarmiento L. J., Feldman C. G., Milligan J. A., Falkowski G. P., Letelier M. R. \& Boss, S. E. (2006) Climate-driven change in contemporary ocean productivity. Nature $\mathbf{4 4 4}, \mathbf{7 5 2 - 7 5 5 .}$

6. Behrenfeld M. (2011) Uncertain future for ocean algae. Nature 1, 33-34.

7. Beardall J. \& Stojcovik S. (2006) Microalgae under global environmental change: Implications for growth and productivity, populations and trophic flow. Science Asia 32, 1-10.

8. Hessen O. D. \& Elser J. J. (2005) Elements of ecology and evolution. Oikos 109, 3-5.

9. Jochum M., Schneider D. F., Crowe P. T., Brose U. \& O'Gorman J. E. (2012) Climate-induced changes in bottom-up and top-down processes independently alter a marine ecosystem. Philos. Trans. R. Soc. Lond. B 367, 2962-2970.

10. Kalista H. P. \& Ulrich S. (2012) Phytoplankton Cell Size: Intra- and Interspecific Effects of Warming and Grazing. PLoS One 7(11), e49632.

11. Marañón E., Cermeño P., Latasa M. \& Tadonléké R. D. (2012) Temperature, resources, and phytoplankton size structure in the ocean. Limnol. Oceanogr. 57, 1266-1278.

12. O'Reilly C. M., Alin S. R., Pilsnier P. D., Cohen A. S. \& McKee, B. A. (2003) Climate change decreases aquatic ecosystem productivity of Lake Tanganyika, Africa. Nature 424, 766-768.

13. Ndebele-Murisa M. R., Musil C. F. \& Raitt L. M. (2012) Phytoplankton biomass and primary production dynamics in Lake Kariba. Lakes Reserv. Res. Manage. 17, 275-289.

14. Maclntyre S., Romero J. R., Silsbe G. M. \& Emery B. M. (2014) Stratification and horizontal exchange in Lake Victoria, East Africa. Limnol. Oceanogr. 59, 1805-1838.

15. IPCC (2014) Climate Change 2014: The Physical science basis. IPCC, WG1

16. Natugonza V., Ogutu-Ohwayo R., Efitre J., Muyodi F., Mbabazi D., Olokotum M., Musinguzi L., Naigaga S. \& Namboowa S. (2015) The responses of Nile tilapia Oreochromis niloticus (Linnaeus, 1758) in Lake Wamala (Uganda) to changing climatic conditions. Lakes Reserv. Res. Manage. 20, 101-119. 
17. Barange M. \& Perry R. I. (2009) Physical and ecological impacts of climate change relevant to marine and inland capture fisheries and aquaculture. In: Climate change implications for fisheries and aquaculture: overview of current scientific knowledge (eds K. Cochrane, C. De Young, D. Soto \& T. Bahri) pp. 7-106. FAO Fisheries and Aquaculture Technical Paper 530, Rome, Italy.

18. Hecky R. E. (1993) The eutrophication of Lake Victoria. Verh. Int. Ver. Theor. Angew. Limnol. 25, 39-48.

19. Mugidde R. (2001) Nutrient Status and Planktonic Nitrogen Fixation in Lake Victoria, Africa. Unpublished PhD Thesis, University of Waterloo, Ontario, Canada.

20. MacDonald W.W. (1953) Lake-flies. Uganda Journal 17, 124-134.

21. Sekiranda S. B. K., Okot-Okumu J., Bugenyi F. W. B., Ndawula L. M., Gandhi P. (2004) Variations in composition of macro-benthic invertebrates as an indication of water quality status in three bays in Lake Victoria. UJAS. 9, 396-411

22. Verschuren D., Johnson T. C., Kling H. J., Edgington D. N., Leavitt P. R., Brown E. T., Talbot M. R., Hecky R. E., (2002) The chronology of human impacts on Lake Victoria, East Africa. Proc. R. Soc. Lond. B. 269, 289294.

23. UNEP (2009) Lake Wamala. Environmental Change Hotspots, Division of Early Warning and Assessment, UNEP. http://na.unep.net/atlas/webatlas.php? Accessed 21 August 2014.

24. Goulden M. C. (2006) Livelihood diversification, social capital and resilience to climate variability among natural resource dependant societies in Uganda. Unpublished PhD Thesis, University of East Anglia, Norwich, UK.

25. Musinguzi L., Efitre J., Odongkara O. K., Ogutu-Ohwayo R., Muyodi F. J., Natugonza V., Olokotum M., Namboowa S. \& Naigaga S. (2015) Fishers' perceptions of climate change, impacts on their livelihoods and adaptation strategies in environmental change hot spots: A case of Lake Wamala, Uganda. Environment, Development and Sustainability DOI 10.1007/s10668-015-9690-6

26. Komutunga E. T. \& Musiitwa F. (2001) Climate. In: Agriculture in Uganda (ed J. K. Mukiibi). Vol I. pp. 2132. Fountain Publ/ CTA/ NARO, Entebbe, Uganda.

27. Wetzel R. G. and G. E. Likens. 2000. Limnological analyses. Springer, New York, USA.

28. American Public Health Association, APHA (1995) Standard methods for the examination of Water and Wastewater.19th Edition, Washington DC, USA.

29. Krom M. D. (1982) Spectrophotometric determination of ammonia: a study of a modified Bertholet reaction using salicylate and dichlorisocyanurate. Analyst 105, 305-316.

30. Utermöhl H. (1958) The improvement of quantitative phytoplankton methodology. Verh. Int. Ver. Theor. Angew. Limnol. 2, 1-38.

31. John D., Whitton M. B. A. \& Brook A. J. (2002) The freshwater algal flora of the British Isles: an identification guide to freshwater and terrestrial algae. Cambridge University Press, Edinburgh, UK.

32. Hillenbrand H., C. D. Durselen, D. Kirschtel, U. Pollingher and T. Zohary. 1999. Biovolume calculation for pelagic and benthic microalgae. Journal of Phycology 35: 403-424.

33. Brooks J. L. (1957) The systematics of North American Daphnia. Mem. Conn. Acad. Arts Sci. 13, 1-18. 
34. Pennak R. W. (1978). Freshwater invertebrates of the United States. Second Edition. John Wiley \& Sons. Pg. 803.

35. Mwebaza-Ndawula L. (1994) Changes in relative abundance of zooplankton in northern Lake Victoria, East Africa. Hydrobiologia 272, 256-64.

36. De Moor I. J., Day J. A. \& De Moor F. C. (2003) Freshwater invertebrates of South Africa. Vol. 8: Insect II. Prepared for the Water Research Commission.

37. OECD (1982) Eutrophication of waters: Monitoring, assessment and control. Washington DC: OECD publications and information centre, pp. 154.

38. Seitzinger S. P. (1988) Denitrification in freshwater and marine ecosystems: Ecological and geochernical significance. Limnol.Oceanogr. 35, 702-724.

39. Gikuma-Njuru P. \& Hecky R. E. (2005) Nutrient concentrations in Nyanza Gulf, Lake Victoria, Kenya: light limits algal demand and abundance. Hydrobiologia 534, 131-140.

40. Talling J. F. (1966) The annual cycle of stratification and phytopl ankton growth in Lake Victoria (East Africa). Int. Rev. Hydrobiol. 51, 545-621.

41. Hecky R. E., Bugenyi F. W. B., Ochumba P., Talling J. F., Mugidde R., Gophen M. \& Kaufman L. (1994) Deoxygenation of the deep water of Lake Victoria, East Africa. Limnol. Oceanogr. 39, 1476-1481.

42. Park S., Brett M. T., Müller-Solger A. \& Goldman C. R. (2004) Climatic forcing and primary productivity in a subalpine lake: Inter-annual variability as a natural experiment. Limnol. Oceanogr. 49, 614-619.

43. Sitoki L., Kurmayer R. \& Rott E. (2012) Spatial variation of phytoplankton composition, biovolume, and resulting microcystin concentrations in the Nyanza Gulf (Lake Victoria, Kenya). Hydrobiologia 691, 109122.

44. Paerl H. W. \& Huisman J. (2009) Climate change: a catalyst for global expansion of harmful cyanobacterial blooms. Environ. Microbiol. Rep. 1, 27-37.

45. Poste A. E., Hecky R. E. \& Guildford S. J. (2013) Phosphorus enrichment and carbon depletion contribute to high Microcystis biomass and microcystin concentrations in Ugandan lakes. Limnol Oceanogr 58, 1075-1088.

46. Tasevska O., Jersabek C. D., Kostoski G. \& Guseska D. (2012) Differences in rotifer communities in two freshwater bodies of different trophic degree (Lake Ohrid and Lake Dojran, Macedonia). Biologia 67, 565572.

47. Lazzaro X. (1997) Do the trophic cascade hypothesis and classical biomanipulation approaches apply to tropical lakes and reservoirs? Verh. Int. Ver. Theor. Angew. Limnol. 26, 719-730.

48. Yildiz S., Altindag A. \& Ergonul M. B. (2007) Seasonal fluctuations in the zooplankton composition of a eutrophic lake: Lake Marmara (Manisha, Turkey). Turk. J. Zool. 31, 26-121.

49. Walshe B. M., (1950) The function of haemoglobin in Chironomus plumosus under natural conditions. J. Exp. Biol. 27, 73-95. 
Table 1 Physical chemical parameters, chlorophyll $a$ and primary production in Lake Wamala between 1999 and 2013 (Data on rainfall and lake depth from Natugonza et al. 2015).

\begin{tabular}{|c|c|c|c|c|c|}
\hline Year & 1999 & 2000 & 2011 & 2012 & 2013 \\
\hline Total annual rainfall (mm) & 1166 & 1294 & 1294 & 1411 & 1300 \\
\hline Mean lake depth (m) & 4.5 & 4.0 & 3.0 & 3.4 & 3.8 \\
\hline Surface temperature $\left({ }^{\circ} \mathrm{C}\right)$ & $25.3 \pm 2.01$ & $26.9 \pm 1.25$ & $23.9 \pm 0.49$ & $25.7 \pm 0.47$ & $25.5 \pm 0.5$ \\
\hline $\mathrm{SD}(\mathrm{m})$ & $0.51 \pm 0.08$ & $0.54 \pm 0.09$ & $0.61 \pm 0.06$ & $0.59 \pm 0.05$ & $0.61 \pm 0.05$ \\
\hline Conductivity $\left(\mu \mathrm{Scm}^{-1}\right)$ & $163.2 \pm 4.96$ & $174.2 \pm 113$ & $321.3 \pm 59.7$ & $387.3 \pm 11.4$ & $367 \pm 20.0$ \\
\hline $\operatorname{SRP}\left(\mu \mathrm{g} \mathrm{L}^{-1}\right)$ & $55.5 \pm 58.3$ & $19.93 \pm 5.42$ & $24.59 \pm 15.15$ & $39.05 \pm 9.02$ & \\
\hline $\mathrm{TP}\left(\mu \mathrm{g} \mathrm{L}^{-1}\right)$ & $137.14 \pm 68.04$ & $90.67 \pm 35.59$ & $54.49 \pm 10.70$ & $303 \pm 69.1$ & \\
\hline $\mathrm{NO}_{2}-\mathrm{N}\left(\mu \mathrm{g} \mathrm{L}^{-1}\right)$ & $3.65 \pm 2.84$ & $0.6 \pm 0.58$ & $3.62 \pm 3.43$ & $5.77 \pm 0.69$ & $2.2 \pm 2.25$ \\
\hline NO3-N $\left(\mu \mathrm{g} \mathrm{L}^{-1}\right)$ & $11.1 \pm 12.85$ & $14.4 \pm 0.41$ & $12.1 \pm 7.95$ & $35.17 \pm 18.5$ & $32.4 \pm 15.8$ \\
\hline $\mathrm{NH} 4-\mathrm{N}\left(\mu \mathrm{g} \mathrm{L}^{-1}\right)$ & $45.39 \pm 29.72$ & $36.1 \pm 17.17$ & $5.51 \pm 1.69$ & $16.65 \pm 2.17$ & $20.06 \pm 8.06$ \\
\hline SRSi $\left(\mu \mathrm{g} \mathrm{L}^{-1}\right)$ & $1957.6 \pm 749.7$ & $4184.0 \pm 915.6$ & $1238 \pm 489.5$ & $8197.4 \pm 2907.2$ & $6452.7 \pm 863.6$ \\
\hline $\mathrm{Chl}$ a $\left(\mu \mathrm{g} \mathrm{L}^{-1}\right)$ & $101.2 \pm 40.9$ & $60.8 \pm 12.5$ & $8.0 \pm 2.57$ & $39.5 \pm 38.72$ & \\
\hline Primary production $\left(\mathrm{mg} \mathrm{O}_{2} \mathrm{~m}^{-2} \mathrm{~h}^{-1}\right)$ & & & $531.5 \pm 108.8$ & $806.6 \pm 258.9$ & \\
\hline
\end{tabular}


Table 2 Occurrence of phytoplankton taxa in Lake Wamala between 1999 and 2013. $p$ and $a$ are aarbitrary letters that denote presence and absence of a particular genus, respectively.

\begin{tabular}{|c|c|c|c|c|c|c|}
\hline Taxonomic group & Genus & 1999 & 2000 & 2011 & 2012 & 2013 \\
\hline Cyanobacteria & Anabaena & $\mathrm{p}$ & a & $\mathrm{p}$ & $\mathrm{p}$ & $p$ \\
\hline Cyanobacteria & Anabaenopsis & $\mathrm{p}$ & $\mathrm{p}$ & $\mathrm{p}$ & $\mathrm{p}$ & $\mathrm{p}$ \\
\hline Cyanobacteria & Aphanocapsa & $\mathrm{p}$ & $\mathrm{p}$ & $\mathrm{p}$ & $p$ & $\mathrm{p}$ \\
\hline Cyanobacteria & Chroococcus & $p$ & $\mathrm{p}$ & $\mathrm{p}$ & $p$ & $\mathrm{p}$ \\
\hline Cyanobacteria & Coelomoron & a & a & $\mathrm{p}$ & $p$ & $\mathrm{p}$ \\
\hline Cyanobacteria & Cyanodyction & a & a & $\mathrm{p}$ & $p$ & $\mathrm{p}$ \\
\hline Cyanobacteria & Cylindrospermopsis & a & $\mathrm{p}$ & $\mathrm{p}$ & $\mathrm{p}$ & $\mathrm{p}$ \\
\hline Cyanobacteria & Merismopedia & $\mathrm{p}$ & $\mathrm{p}$ & $\mathrm{p}$ & $\mathrm{p}$ & $\mathrm{p}$ \\
\hline Cyanobacteria & Microcystis & $p$ & $\mathrm{p}$ & $\mathrm{p}$ & $\mathrm{p}$ & $\mathrm{p}$ \\
\hline Cyanobacteria & Planktolyngbya & $p$ & $\mathrm{p}$ & $\mathrm{p}$ & $\mathrm{p}$ & $\mathrm{p}$ \\
\hline Cyanobacteria & psuedoanabeana & a & a & $\mathrm{p}$ & $\mathrm{p}$ & $\mathrm{p}$ \\
\hline Cyanobacteria & Romeria & a & a & $\mathrm{p}$ & $p$ & a \\
\hline Diatoms & Aulacoseira & a & a & $p$ & $\mathrm{p}$ & $\mathrm{p}$ \\
\hline Diatoms & Cyclostephanodiscus & $\mathrm{p}$ & a & $p$ & $\mathrm{p}$ & a \\
\hline Diatoms & Cyclotella & $\mathrm{p}$ & $\mathrm{p}$ & $\mathrm{p}$ & a & a \\
\hline Diatoms & Daitoma & a & $\mathrm{p}$ & a & a & a \\
\hline Diatoms & Epitheimia & a & a & a & $\mathrm{p}$ & a \\
\hline Diatoms & Nitzschia & $\mathrm{p}$ & $\mathrm{p}$ & $\mathrm{p}$ & $\mathrm{p}$ & $\mathrm{p}$ \\
\hline Diatoms & Surirella & a & a & a & $\mathrm{p}$ & a \\
\hline Diatoms & Synedra & $\mathrm{p}$ & a & a & $\mathrm{p}$ & $\mathrm{p}$ \\
\hline Diatoms & Tabellaria & a & $\mathrm{p}$ & a & a & a \\
\hline Dinoflagellates & Glenodinium & a & a & a & $p$ & $\mathrm{p}$ \\
\hline Dinoflagellates & Peridinium & a & a & $\mathrm{p}$ & $\mathrm{p}$ & $p$ \\
\hline
\end{tabular}




\begin{tabular}{|c|c|c|c|c|c|c|}
\hline Euglenophytes & Euglena & $\mathrm{p}$ & $\mathrm{p}$ & $\mathrm{p}$ & $\mathrm{p}$ & $\mathrm{a}$ \\
\hline Euglenophytes & Lepocinclis & a & a & $\mathrm{p}$ & a & $\mathrm{p}$ \\
\hline Euglenophytes & Phacus & $\mathrm{p}$ & $\mathrm{p}$ & $\mathrm{p}$ & $\mathrm{p}$ & $\mathrm{a}$ \\
\hline Euglenophytes & Trachelomonas & $a$ & a & $\mathrm{p}$ & $\mathrm{p}$ & $\mathrm{a}$ \\
\hline Green & Ankistrodesmus & $\mathrm{p}$ & $\mathrm{p}$ & $\mathrm{p}$ & a & $\mathrm{p}$ \\
\hline Green & Chodatella & $a$ & a & $\mathrm{p}$ & a & a \\
\hline Green & Coelastrum & a & a & $\mathrm{p}$ & $\mathrm{p}$ & a \\
\hline Green & Cosmorium & a & $\mathrm{p}$ & a & a & a \\
\hline Green & Crucigenia & a & $a$ & $\mathrm{p}$ & $\mathrm{p}$ & $\mathrm{p}$ \\
\hline Green & Didymocystis & a & a & a & $\mathrm{p}$ & a \\
\hline Green & Kirchnriella & a & a & a & $\mathrm{p}$ & $\mathrm{p}$ \\
\hline Green & Monorophidium & a & a & $\mathrm{p}$ & $\mathrm{p}$ & $\mathrm{p}$ \\
\hline Green & Oosystis & a & a & a & $\mathrm{p}$ & a \\
\hline Green & Pediastrum & $\mathrm{p}$ & $a$ & a & $\mathrm{p}$ & $\mathrm{p}$ \\
\hline Green & Scenedesmus & $\mathrm{p}$ & $\mathrm{p}$ & $\mathrm{p}$ & $\mathrm{p}$ & $\mathrm{p}$ \\
\hline Green & Selenestrum & a & a & a & a & $\mathrm{p}$ \\
\hline Green & Tetraedron & $\mathrm{p}$ & a & a & $\mathrm{p}$ & $\mathrm{p}$ \\
\hline
\end{tabular}

Table 3 Changes in algal biovolume, mean \pm standard deviation $\left(\mu \mathrm{g} \mathrm{L}^{-1}\right)$, of major taxonomic groups identified in Lake Wamala during 1999-2013.

\begin{tabular}{llllll}
\hline Year & 1999 & 2000 & 2011 & 2012 & 2013 \\
\hline Cyanobacteria & $174.5 \pm 138.83$ & $134.15 \pm 62.92$ & $693.9 \pm 572.13$ & $2464.13 \pm 3153.6$ & $628.36 \pm 321$ \\
Green algae & $17.36 \pm 18.41$ & $34.4 \pm 18.41$ & $12.41 \pm 6.73$ & $152.32 \pm 110.18$ & $587.28 \pm 314.52$ \\
Diatoms & $37.79 \pm 34.06$ & $32.14 \pm 9.77$ & $1707.12 \pm 2883.7$ & $9600.19 \pm 1321.4$ & $607.33 \pm 376.81$ \\
Cryptophytes & - & - & 43.86 & $775.76 \pm 587.48$ & - \\
Euglenophytes & $11.64 \pm 6.05$ & 7.45 & $1985.02 \pm 890.9$ & $6529.34 \pm 6088.33$ & -
\end{tabular}


Table 4 Density of major zooplankton taxa, mean \pm standard error (individuals/litre), in Lake Wamala between 1998 and 2013

\begin{tabular}{|c|c|c|c|c|c|}
\hline Year & 1998 & 2000 & 2011 & 2012 & 2013 \\
\hline \multicolumn{6}{|l|}{ Copepoda } \\
\hline Mesocyclops sp. & $1,327 \pm 593$ & - & $3,146 \pm 1,189$ & $273 \pm 64$ & $580 \pm 124$ \\
\hline $\begin{array}{l}\text { Thermocyclops } \\
\text { decipiens }\end{array}$ & - & - & - & $236 \pm 56$ & $802 \pm 171$ \\
\hline T. neglectus & $7,551 \pm 3,377$ & $2,480 \pm 1,012$ & $2,196 \pm 830$ & $\begin{array}{l}4,563 \pm \\
1,075\end{array}$ & $5,973 \pm 1,273$ \\
\hline \multicolumn{6}{|l|}{ Cladocera } \\
\hline Bosmina longirostris & $204 \pm 91$ & $22,862 \pm 9,333$ & - & $729 \pm 172$ & - \\
\hline Ceriodaphnia cornuta & $3,810 \pm 1,704$ & $2,697 \pm 1,101$ & $144 \pm 54$ & $659 \pm 155$ & $3,608 \pm 769$ \\
\hline Diaphanosoma excisum & - & - & - & $175 \pm 41$ & $433 \pm 92$ \\
\hline Moina micrura & $17,653 \pm 7,895$ & $5,492 \pm 2,242$ & $6,763 \pm 2,556$ & $2,988 \pm 704$ & $\begin{array}{l}12,681 \pm \\
2,704\end{array}$ \\
\hline \multicolumn{6}{|l|}{ Rotifera } \\
\hline Ascomorpha sp. & $19,728 \pm 8,823$ & $2,637 \pm 1,077$ & - & $141 \pm 33$ & $939 \pm 200$ \\
\hline Asplanchna sp. & $55,646 \pm 24,886$ & $1,203 \pm 491$ & $644 \pm 243$ & $275 \pm 65$ & $393 \pm 84$ \\
\hline Brachionus angularis & $2,347 \pm 1,050$ & $99,226 \pm 40,509$ & $\begin{array}{l}36,067 \pm \\
13,632\end{array}$ & $\begin{array}{l}9,993 \pm \\
2,355\end{array}$ & $\begin{array}{l}18,480 \pm \\
3,940\end{array}$ \\
\hline B. bidentatus & - & $1,795 \pm 733$ & $1,528 \pm 577$ & - & $3 \pm 1$ \\
\hline B. budapestinensis & - & - & $8,922 \pm 3,372$ & - & - \\
\hline B. calyciflorus & $7,891 \pm 3,529$ & $2,105 \pm 859$ & $672 \pm 254$ & $669 \pm 158$ & $1,542 \pm 329$ \\
\hline B. caudatus & $31,190 \pm 13,949$ & $453 \pm 185$ & - & $41 \pm 10$ & - \\
\hline B. falcatus & - & $4,408 \pm 1,799$ & $2,057 \pm 778$ & $110 \pm 26$ & $1,057 \pm 225$ \\
\hline B. forficula & - & & $165 \pm 62$ & - & - \\
\hline B. patulus & - & $99 \pm 40$ & - & - & - \\
\hline B. quadridentatus & - & $742 \pm 303$ & - & - & - \\
\hline
\end{tabular}




\begin{tabular}{llllll}
\hline Euclanis sp. & - & $32 \pm 13$ & - & - & - \\
Filinia longiseta & - & $212 \pm 87$ & $11,449 \pm 4,327$ & $670 \pm 158$ & $3,791 \pm 808$ \\
F. opoliensis & $2,551 \pm 1,141$ & $32 \pm 13$ & $53,667 \pm$ & $713 \pm 168$ & $1,569 \pm 335$ \\
& & & 20,284 & & \\
Hexathra sp. & - & $24,097 \pm 9,838$ & $6,617 \pm 2,501$ & $156 \pm 37$ & $266 \pm 57$ \\
K. cochlearis & $408 \pm 183$ & $651 \pm 266$ & $380 \pm 144$ & $48 \pm 11$ & $279 \pm 59$ \\
K. tropica & $663,163 \pm 296,57$ & $161,906 \pm 66,09$ & $84,291 \pm$ & $3,340 \pm 787$ & $20,460 \pm$ \\
& 6 & 8 & 31,859 & & 4,362 \\
Lecane bulla & $1,837 \pm 821$ & $1,180 \pm 482$ & $3,947 \pm 1,492$ & $1,195 \pm 282$ & $2,183 \pm 465$ \\
L. luna & - & - & - & $593 \pm 140$ & $7,013 \pm 1,495$ \\
Polyathra vulgaris & - & $2,963 \pm 1,210$ & $3,497 \pm 1,322$ & $505 \pm 119$ & $412 \pm 88$ \\
Polyarthra sp. & $193,877 \pm 86,705$ & $340 \pm 139$ & $667 \pm 252$ & - & - \\
Syncheata pectinata & - & $8,200 \pm 3,348$ & - & & - \\
Synchaeta sp. & - & $4,527 \pm 1,848$ & $7,847 \pm 2,966$ & $683 \pm 161$ & $599 \pm 128$ \\
Tricorca cylindrica & $68,605 \pm 30,681$ & $3,035 \pm 1,239$ & $1,902 \pm 719$ & $4,107 \pm 968$ & $378 \pm 81$ \\
Trichotria tetractis & - & $4,074 \pm 1,663$ & - & - & - \\
\hline & & & & & \\
\hline
\end{tabular}

Table 5 Density of benthic macro-invertebrate taxa, mean \pm standard deviation (individuals $/ \mathrm{m}^{2}$ ), in Lake Wamala between 1999 and 2013. Arbitrary letter (a) denotes absence of a particular specie or genus

\begin{tabular}{|c|c|c|c|c|}
\hline Year & 1999 & 2000 & 2012 & 2013 \\
\hline \multicolumn{5}{|l|}{ Molluscs } \\
\hline Bulinus sp. & a & a & $1 \pm 3$ & a \\
\hline \multicolumn{5}{|c|}{ Ephemeroptera nymphs } \\
\hline Caenis sp. & a & a & $21 \pm 81$ & a \\
\hline Cloeon sp. & $a$ & a & $1 \pm 3$ & $a$ \\
\hline Povilla adusta & a & a & $2 \pm 10$ & a \\
\hline Diptera & & & & \\
\hline
\end{tabular}




\begin{tabular}{lllll}
\hline Ablabesmyia sp. & $\mathrm{a}$ & $\mathrm{a}$ & $9 \pm 25$ & $\mathrm{a}$ \\
Chironomus sp. & $292 \pm 482$ & $224 \pm 237$ & $276 \pm 916$ & $142 \pm 139$ \\
Clinotanypus sp. & $\mathrm{a}$ & $\mathrm{a}$ & $27 \pm 26$ & $33 \pm 41$ \\
Procladius sp. & $\mathrm{a}$ & $\mathrm{a}$ & $120 \pm 103$ & $81 \pm 91$ \\
Tanypus sp. & $\mathrm{a}$ & $\mathrm{a}$ & $4 \pm 10$ & $7 \pm 14$ \\
Chaoborus sp. & $184 \pm 227$ & $282 \pm 130$ & $290 \pm 322$ & $293 \pm 229$ \\
\hline Others & & & & \\
\hline Ostracoda & $2 \pm 7$ & $\mathrm{a}$ & $2 \pm 6$ & $\mathrm{a}$ \\
Tanypodinae & $51 \pm 77$ & $44 \pm 55$ & $\mathrm{a}$ & $\mathrm{a}$ \\
Chironominea & $5 \pm 13$ & $\mathrm{a}$ & $\mathrm{a}$ & $1 \pm 4$ \\
Hydracharina & $1 \pm 3$ & $\mathrm{a}$ & $\mathrm{a}$ & $\mathrm{a}$ \\
Hirudinea & $1 \pm 3$ & $\mathrm{a}$ & $\mathrm{a}$ & $\mathrm{a}$ \\
Oligochaeta & $8 \pm 22$ & $3 \pm 5$ & $11 \pm 35$ & $1 \pm 4$ \\
\hline & & & & \\
\hline
\end{tabular}

\section{Figure captions}

Figure 1 Location of Lake Wamala and sampling stations (inset is location of Uganda within Africa)

Figure 2 Seasonal variations in different elements of phosphorus $(a, b)$, nitrogen (c-e) and, integral primary production ( $f$ ) in Lake Wamala between 2011 and 2013

Figure 3 Seasonal variations in chlorophyll $a$ in Lake Wamala between 2011 and 2013

Figure 4 Relative abundance of three major algal groups in Lake Wamala during different seasons between 2011 and 2013. 


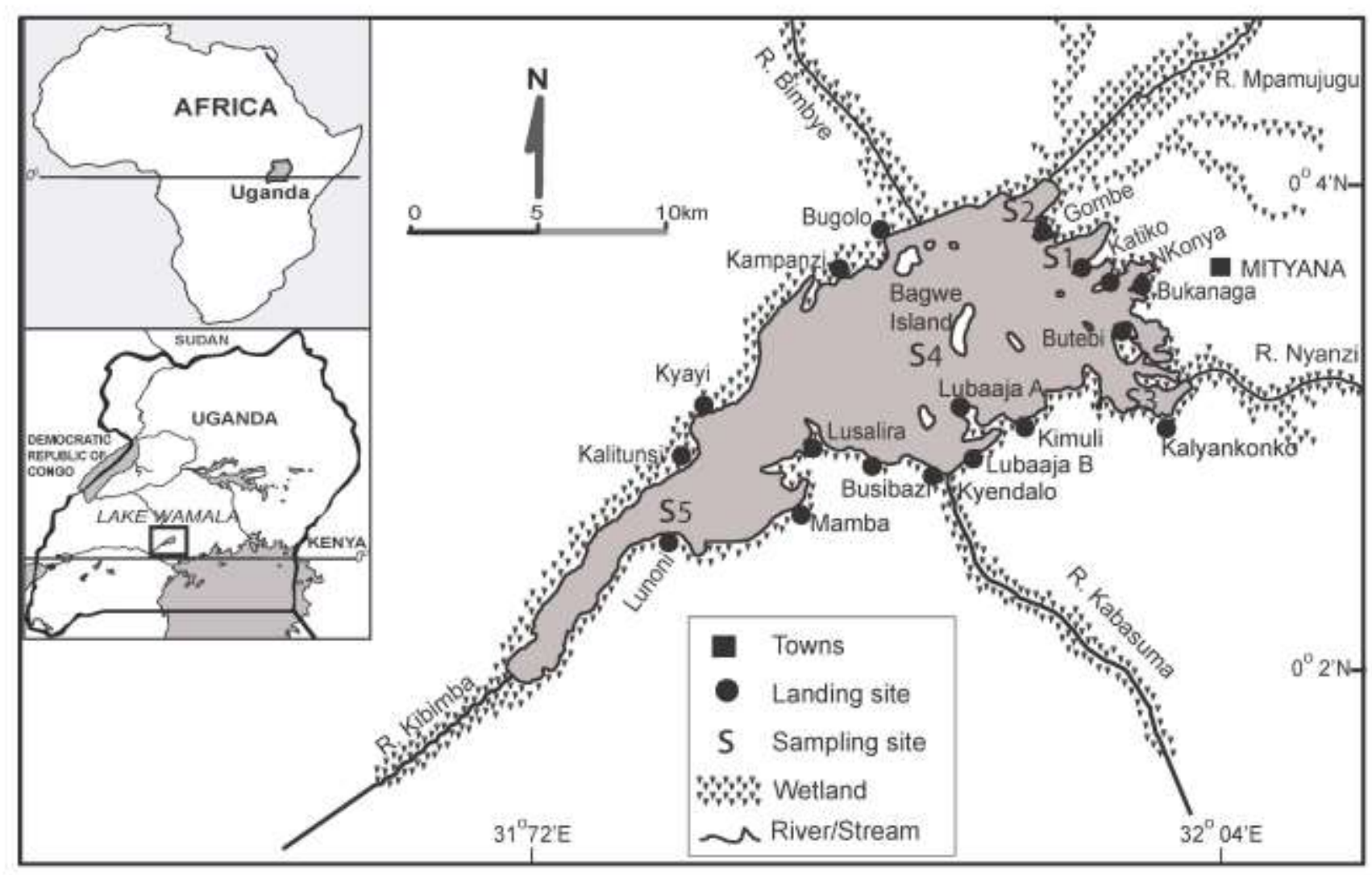

Figure 1 Location of Lake Wamala and sampling stations (inset is location of Uganda within Africa) 

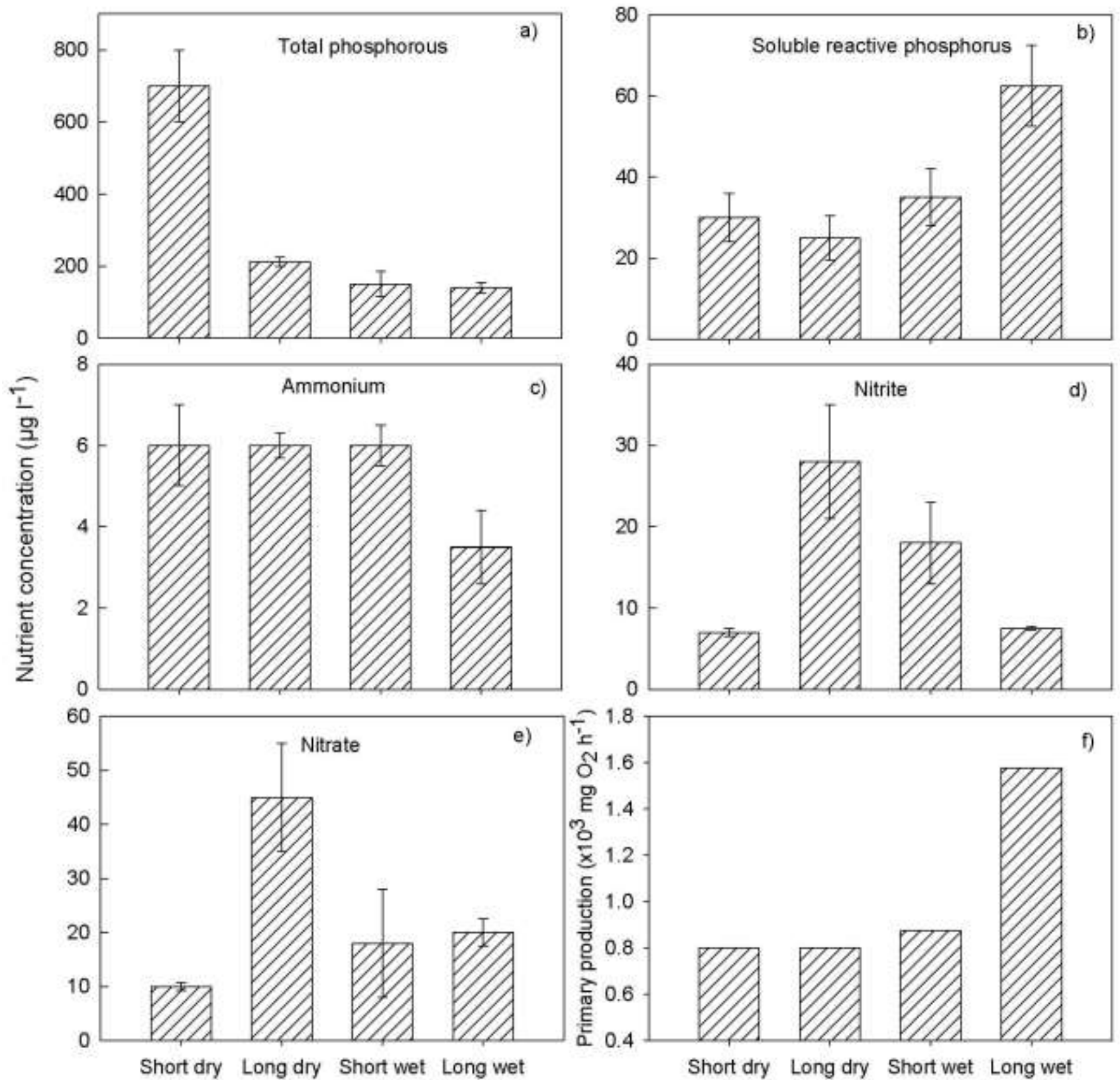

Sampling season

Figure 2 Seasonal variations in different elements of phosphorus $(a, b)$, nitrogen (c-e) and, integral primary production $(f)$ in Lake Wamala between 2011 and 2013 


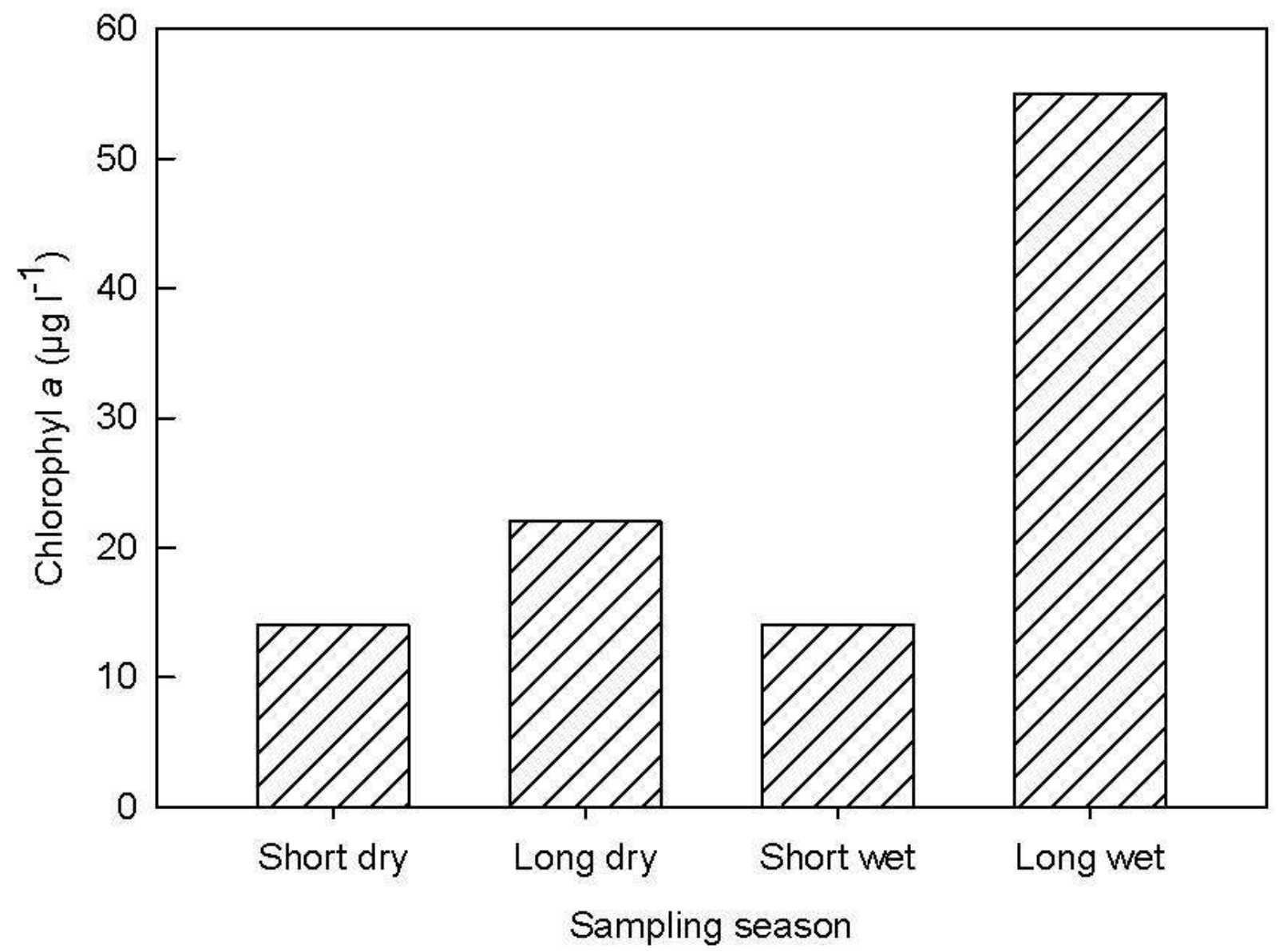

Figure 3 Seasonal variations in chlorophyll a in Lake Wamala between 2011 and 2013 


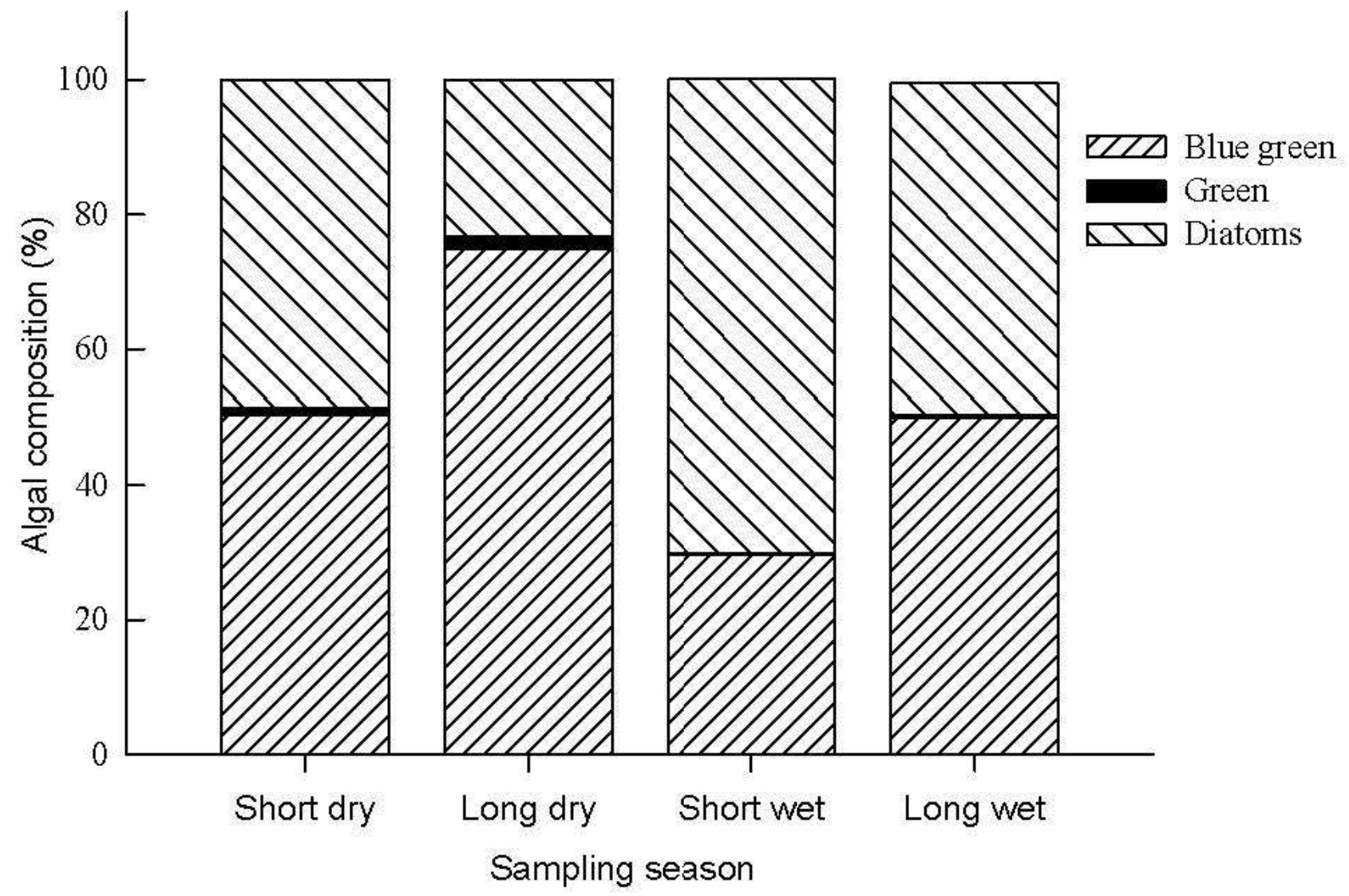

Figure 4 Relative abundance of three major algal groups in Lake Wamala during different seasons between 2011 and 2013 